\title{
Permintaan Gula Kristal Mentah Indonesia
}

\section{The Demand for Raw Sugar in Indonesia}

\author{
Rutte Indah Kurniasari ${ }^{1}$, Dwidjono Hadi Darwanto ${ }^{2}$, dan Sri Widodo ${ }^{2}$ \\ ${ }^{1}$ Mahasiswa S2 Ekonomi Pertanian, Fakultas Pertanian UGM \\ ${ }^{2}$ Staf Dosen Fakultas Pertanian UGM, Kampus Bulaksumur, Yogyakarta
}

\begin{abstract}
This study aimed to determine the factors that influence the demand for imported raw sugar and to make a projection about the demand for raw sugar in the future. The research method used Ordinary Least Square (OLS) regression analysis to determine the factors that influence the demand for imported raw sugar. Then the trend analysis used to determine the tendency of imported raw sugar in the future. The results showed that the factors which significantly affected the demand for imported raw sugar are the production of Indonesian white sugar, the national sugar consumption and the world price of raw sugar. Imports of raw sugar will increase as long as the number of national sugar consumption increasing for each year, as long as Indonesia does not attempt to start producing its own raw sugar crystals. The trend of imported raw sugar by Indonesia tend to rise or increase from year to year. Based on the trend analysis, it can be estimated that in 2020 the number of imported raw sugar in indonesia will be 1,219,979 tons.
\end{abstract}

Keywords: Regression Analysis, Trend Analysis, Raw Sugar Imports

\section{INTISARI}

Penelitian ini bertujuan untuk mengetahui faktor-faktor yang mempengaruhi permintaan gula kristal mentah impor dan memproyeksikan permintaan gula kristal mentah di masa yang akan datang. Metode penelitian yang dipergunakan adalah metode analisis regresi Ordinary Least Square (OLS) untuk mengetahui faktor-faktor yang mempengaruhi permintaan gula kristal mentah impor. Selanjutnya digunakan analisis trend untuk mengetahui kecenderungan trend permintaan gula kristal mentah impor dimasa yang akan datang. Hasil penelitian menunjukkan bahwa faktor yang berpengaruh secara signifikan terhadap permintaan gula kristal mentah impor adalah produksi gula kristal putih Indonesia, konsumsi gula nasional dan harga gula kristal mentah dunia. Impor gula kristal mentah akan terus meningkat per tahunnya seiring dengan meningkatnya jumlah konsumsi gula nasional, selama Indonesia tidak berupaya untuk mulai memproduksi gula kristal mentahnya sendiri. Trend impor gula kristal mentah oleh Indonesia cenderung naik atau meningkat dari tahun ke tahun. Berdasarkan hasil analisis trend, dapat diperkirakan bahwa Indonesia pada tahun 2020 jumlah impor gula kristal mentahnya bisa mencapai 1.219.979 ton.

Kata Kunci: Analisis Regresi, Tren Analisis, Gula Kristal Mentah Impor

\section{PENDAHULUAN}

Di Indonesia gula merupakan komoditas terpenting nomor dua setelah beras. Gula menjadi begitu penting bagi masyarakat yakni sebagai sumber kalori. Pada umumnya gula digunakan untuk mengawetkan makanan dan untuk pemanis. Gula di Indonesia terdapat berbagai jenis berdasarkan bahan pembuatnya misalnya gula tebu, gula aren dan gula kelapa. Untuk gula tebu sendiri dapat dibedakan menjadi tiga, yakni Gula Kristal Mentah (GKM) atau raw sugar, Gula Kristal Putih (GKP) dan Gula Kristal Rafinasi (GKR). Gula kristal mentah (GKM) merupakan gula yang digunakan sebagai bahan baku untuk produksi gula rafinasi dan sebagian untuk gula kristal putih. Gula kristal putih merupakan gula yang terbuat dari kristalisasi yang dapat langsung digunakan untuk konsumsi rumah tangga, sedangkan GKR merupakan gula yang digunakan untuk memenuhi kebutuhan industri seperti industri makanan, minuman dan farmasi.

Kebutuhan Indonesia akan gula akan terus meningkat seiring dengan bertambahnya jumlah penduduk dan juga kenaikan pendapatan. Organisasi Gula Internasional (ISO) menyatakan bahwa konsumsi gula Indonesia akan tumbuh $4 \%$ per tahun untuk memenuhi kebutuhan 240 juta jiwa penduduk nasional. Berdasarkan data Tahun 
2012 menunjukkan bahwa total kebutuhan konsumsi gula untuk industri sebesar 2,5 juta ton per tahun. Namun, permintaan tersebut tak seimbang dengan total gula kristal rafinasi yang ditawarkan oleh produksi dalam negeri yakni hanya sebesar 2,1 juta ton per tahun. Berdasarkan data tersebut diketahui bahwa terjadi ketidakseimbangan antara permintaan dan penawaran, yakni untuk GKR terjadi defisit 400.000 ton. Untuk memenuhi kebutuhan gula Indonesia, pemerintah mengambil kebijakan untuk mengimpor kekurangannya dari luar negeri.

Sebelum tahun 2000, Indonesia mengimpor seluruh kebutuhan gula rafinasi. Namun ekspektasi gula dunia terus meningkat sedangkan produksi di dalam negeri semakin menurun sehingga pemerintah memutuskan untuk membangun pabrik gula rafinasi. Hingga tahun 2009, Indonesia memiliki delapan pabrik gula rafinasi. Gula kristal rafinasi sendiri merupakan gula dengan bahan baku berupa gula kristal mentah. Di Indonesia, seluruh kebutuhan gula kristal mentah pabrik-pabrik gula rafinasi dipenuhi dari impor.

ISO memperkirakan pada tahun 20122013 impor gula kristal mentah Indonesia akan semakin meningkat bahkan akan melampaui China yang kemudian akan membuat Indonesia menjadi negara importir gula kristal mentah (GKM) nomor satu di Dunia. China mencoba mengurangi impor GKM dengan cara membangun pabrik gula rafinasi dan untuk menggenjot produksi gula dalam negeri, China juga membuka lahan untuk budidaya tebu. Namun di Indonesia

$$
I r=\beta_{0} P D R f^{\beta_{1}} \cdot P D P^{\beta_{2}} \cdot C S d^{\beta_{3}} \cdot P R w^{\beta_{4}} \cdot S P R^{\beta_{5}} \cdot T R^{\beta_{6}}
$$

Persamaan tersebut dijadikan persamaan logaritma natural sehingga menjadi,

$$
\ln I r=\ln \beta_{0}+\beta_{1} \ln P D R f+\beta_{2} \ln P D P+\beta_{3} \ln C S d+\beta_{4} \ln P R w+\beta_{5} \ln S P R+\beta_{6} \ln T R+\varepsilon
$$

Dimana,

Ir $\quad=$ Permintaan gula kristal mentah impor (ton/tahun)

PDRf = Produksi gula kristal rafinasi Indonesia (ton/tahun)

PDP = Produksi gula kristal putih Indonesia (ton/tahun)

$\mathrm{CSd}=$ Konsumsi gula nasional (ton/tahun)

$\mathrm{PRw}=$ Harga gula kristal mentah dunia (US\$/ton)

SPR = Rasio harga gula kristal putih

$\mathrm{TR}=$ Tarif impor gula mentah $(\mathrm{Rp} / \mathrm{kg})$

$\varepsilon \quad=$ Faktor kesalahan

Proyeksi perkembangan impor gula kristal mentah dapat diperoleh dengan mengestimasi justru saat ini baru memiliki delapan pabrik gula rafinasi dan dua masih dalam pembangunan. Selain itu, Indonesia terkendala cuaca dan lahan yang sesuai untuk budidaya tebu minim tersedia, sehingga sulit bagi Indonesia untuk memperluas lahan budidaya tebu khususnya di Pulau Jawa.

\section{BAHAN DAN METODE}

Metode yang digunakan dalam penelitian ini adalah metode desktiptif analisis. Jenis data yang dipergunakan adalah data sekunder yang berupa data time-series dengan runtun waktu dari tahun 1983 hingga 2011. Sumber data dalam penelitian ini adalah BPS, Kementerian Pertanian, Dewan Gula Indonesia, FAO, Asosiasi Gula Rafinasi Indonesia serta data-data dari instansi lain yang berkaitan dengan penelitian.

Pada penelitian ini, kualitas gula kristal mentah impor yang diminta dianggap memiliki kualitas yang sama yakni nilai ICUMSA minimal 1200 IU sesuai dengan Peraturan Menteri Keuangan Nomor 150/PMK.011/2009. Pada penelitian ini untuk menganalisis bahwa permintaan gula kristal mentah impor sebagai input produksi gula (GKP dan GKR) diduga dipengaruhi oleh produksi gula kristal rafinasi Indonesia, produksi gula kristal putih Indonesia, konsumsi gula nasional, harga gula kristal mentah dunia, rasio harga gula kristal putih dan tarif impor gula mentah.

Pada penelitian ini digunakan model langsung Cobb-Douglass dengan bentuk umum sebagai berikut:

volume impor dengan menggunakan persamaan trend dengan metode Least Square. Persamaan trend dengan metode Least Square adalah sebagai berikut :

$\mathrm{Ir}=\mathrm{a}+\mathrm{bT}$

Keterangan:

Ir $=$ Permintaan gula kristal mentah impor (ton/tahun)

a $\quad=$ Intersep

$\mathrm{b}=$ Koefisien regresi pengubah waktu

$\mathrm{T} \quad=$ Waktu 


\section{HASIL DAN PEMBAHASAN}

Permintaan gula kristal mentah impor menunjukkan seberapa besar jumlah gula kristal mentah impor yang diminta oleh Indonesia untuk memproduksi gula kristal rafinasi dan gula kristal putih dalam negeri. Untuk mengetahui faktorfaktor yang mempengaruhi permintaan gula kristal mentah impor di Indonesia digunakan model penaksir parameter logaritma natural (ln) agar variabel-variabel yang digunakan dalam analisis ini lebih terdistribusi normal dan dapat diketahui elastisitasnya. Tabel 1 adalah hasil analisis regresi fungsi permintaan gula kristal mentah impor dengan bantuan software Eviews.

Berdasarkan tabel 1, hasil analisis fungsi permintaan gula kristal mentah impor di Indonesia memiliki koefisien determinasi (R2) sebesar 0,466 yang artinya $46,6 \%$ variasi permintaan gula kristal mentah impor di Indonesia dapat dijelaskan oleh variabel bebas (independent variable) yang digunakan dalam model. Sedangkan 53,4\% dari variasi permintaan gula kristal mentah impor di Indonesia dijelaskan oleh variabel bebas (independent variable) yang tidak digunakan dalam model.

Uji F yang digunakan untuk mengetahui secara statistik bahwa pengaruh variabel bebas secara bersama-sama memberikan pengaruh terhadap variabel tak bebasnya. Berdasarkan tabel 1 diketahui bahwa nilai $\mathrm{F}$ hitung sebesar 3,053641 lebih besar dari $\mathrm{F}$ tabel $(2,64)$ pada tingkat signifikasi $95 \%$. Hal ini berarti variabel bebas berupa produksi gula kristal rafinasi Indonesia, produksi gula kristal putih Indonesia, konsumsi gula nasional, harga gula kristal mentah dunia, rasio harga gula kristal putih, dan tarif impor gula mentah secara bersama-sama berpengaruh nyata terhadap perubahan permintaan gula kristal mentah impor di Indonesia dengan tingkat kepercayaan $95 \%$.

Tabel 1. Hasil Analisis Regresi Fungsi Permintaan Gula Kristal Mentah Impor di Indonesia Tahun 1983-2011

\begin{tabular}{lccrc}
\hline \multicolumn{1}{c}{ Variabel } & Koefisien & Tanda Harapan & t-hitung & Probabilitas \\
\hline Konstanta & $0,9635 \mathrm{~ns}$ & + & 0,8119 & 0,4260 \\
Produksi Gula Kristal Rafinasi Indonesia & $-0,0923 \mathrm{~ns}$ & - & $-0,4773$ & 0,6381 \\
Produksi Gula Kristal Putih Indonesia & $-27,5628^{* *}$ & - & $-2,4332$ & 0,0240 \\
Konsumsi Gula Nasional & $26,2813^{* *}$ & + & 2,5124 & 0,0202 \\
Harga Gula Kristal Mentah Dunia & $12,3478^{* *}$ & + & 2,5617 & 0,0182 \\
Rasio Harga Gula Kristal Putih & $-5,6491 \mathrm{~ns}$ & - & $-1,0577$ & 0,3022 \\
Tarif Impor Gula Kristal Mentah & $-0,0493 \mathrm{~ns}$ & - & $-0,2122$ & 0,8340 \\
\hline $\mathrm{R}^{2}$ & 0,4659 & & & \\
F-statistik & $3,0536^{* *}$ & & & \\
Probabilitas & 0,0262 & & & \\
\hline
\end{tabular}

Sumber: Analisis Data Sekunder, 2013

Keterangan:

*** : Signifikan pada $\alpha=99 \%$

* $\quad$ : Signifikan pada $\alpha=90 \%$

Untuk mengetahui pengaruh variabel bebas secara parsial terhadap variabel tak bebasnya digunakan uji t. Hasil analisis yang ditunjukkan pada tabel 1 di atas terdapat tiga variabel bebas yang berpengaruh nyata yaitu produksi gula kristal putih Indonesia, konsumsi gula nasional, harga gula kristal mentah dunia. Variabel yang tidak berpengaruh nyata adalah produksi gula kristal rafinasi Indonesia, rasio gula kristal putih dan tarif impor gula mentah. Variabel produksi gula kristal putih Indonesia berpengaruh nyata terhadap permintaan gula kristal mentah impor di Indonesia. Hal ini dapat dilihat dari nilai t hitung yakni sebesar $-2,43$ yang signifikan pada
** : Signifikan pada $\alpha=95 \%$

ns : Non Signifikan

tingkat kepercayaan 95\%. Nilai koefisien 27,56275 yang artinya bila produksi mengalami kenaikan $1 \%$ maka akan diikuti oleh penurunan impor gula kristal mentah sebesar $27,56 \%$ sehingga dari analisis regresi tersebut dapat dikatakan bahwa produksi gula kristal putih yang mengalami kenaikan berpengaruh nyata secara statistik terhadap permintaan impor gula kristal mentah di Indonesia. Hal tersebut disebabkan kebijakan yang digalakan oleh pemerintah untuk terus mengenjot hasil produksi gula dalam negeri melalui program kebijakan akselerasi gula. Program akselerasi yang diterapkan oleh pemerintah merupakan program untuk 
mengoptimalkan kinerja pabrik gula yang ada melalui penataanatau rehabilitasi tanaman, rehabilitasi penyehatan mesin pabrik, manajemen pabrik gula dan penyehatan lembaga penelitian yang ada (P3GI).

Variabel konsumsi gula nasional berpengaruh nyata terhadap permintaan gula kristal mentah impor di Indonesia. Hal ini dapat dilihat dari nilai t hitung yakni sebesar 2,51 yang signifikan pada tingkat kepercayaan 95\%. Nilai koefisien 26,28134 yang artinya bila konsumsi gula nasional mengalami kenaikan 1\% maka akan diikuti oleh kenaikan impor gula kristal mentah sebesar 26,28\% sehingga dari analisis regresi tersebut dapat dikatakan bahwa konsumsi gula nasional yang mengalami kenaikan berpengaruh nyata secara statistik terhadap permintaan impor gula kristal mentah di Indonesia. Hal tersebut disebabkan karena kenaikan antara jumlah produksi dan jumlah konsumsi yang tidak sebanding, bahkan menurut Kementerian Perindustrian tahun 2009 Indonesia telah mengalami defisit sebesar 2.350 .000 ton dan diperkirakan tahun 2014 defisit akan mencapai 2.100.264 ton. Hal tersebutlah yang menjadi alasan mengapa kenaikan jumlah konsumsi gula diikuti juga dengan kenaikan jumlah gula kristal mentah yang diimpor, yakni untuk bisa

digunakan sebagai bahan baku produksi gula dalam negeri sehingga hasil produksinya bisa untuk menutupi defisit gula yang telah terjadi. Sehingga sangat wajar bila jumlah impor gula kristal mentah terus meningkat seiring kenaikan jumlah konsumsi gula, selama Indonesia masih belum mampu mengoptimalkan produksi gula dalam negeri.

Variabel harga gula kristal mentah dunia berpengaruh nyata terhadap permintaan gula kristal mentah impor di Indonesia. Hal ini dapat dilihat dari nilai t hitung yakni sebesar 2,56, signifikan pada tingkat kepercayaan 95\%. Nilai koefisien 12,34779 yang artinya bila harga gula kristal mentah dunia mengalami kenaikan $1 \%$ maka akan diikuti oleh kenaikan impor gula kristal mentah sebesar $12,34 \%$ sehingga dari analisis regresi tersebut dapat dikatakan bahwa produksi gula kristal putih yang mengalami kenaikan berpengaruh nyata secara statistik terhadap permintaan impor gula kristal mentah di Indonesia. Hal tersebut terjadi karena pada dasarnya Indonesia merupakan negara yang masih sangat tergantung dengan gula kristal mentah impor, bahkan dapat dikatakan Indonesia 100\% mengimpor gula kristal mentah yang dibutuhkan oleh industri gula dalam negeri sebagai bahan baku. Sehingga berapapun harga dari gula kristal mentah dunia maka Indonesia akan tetap mengimpornya. Dalam hal ini setiap kenaikan harga sebesar $1 \%$ akan meningkatkan juga jumlah gula kristal mentah yang diimpor, karena pada dasarnya harga akan terus meningkat tiap waktunya, begitu juga dengan jumlah konsumsi maka jadi hal yang wajar bila Indonesia justru meningkatkan jumlah impornya meski mengalami kenaikan harga. Sebab, apabila Indonesia mengurangi jumlah impor sedangkan konsumsi terus meningkat, dan produksi gula dalam masih belum bisa memenuhi maka yang terjadi adalah defisit yang terus meningkat dan sebagian kebutuhan gula jadi tidak terpenuhi.

Indonesia pada periode 2011-2012 sebagai negara yang mengkonsumsi gula terbesar dengan peringkat ketujuh di dunia, dan sebagai importir gula peringkat keempat, menunjukkan seberapa besar ketergantungan Indonesia terhadap gula. Tingkat konsumsi yang terus meningkat tiap tahunnya dengan tingkat kenaikan jumlah produksi gula dalam negeri yang tak setara kenaikannya membuat Indonesia harus berfikir lebih cermat untuk dapat menutup semua defisit gula yang terjadi. Salah satu langkah yang di ambil oleh pemerintah ialah dengan melakukan impor bahan baku, dengan harapan bisa memenuhi kebutuhan gula juga sebagai nilai tambah bagi produksi gula dalam negeri. Dengan mengimpor gula mentah sebagai bahan baku artinya memberi kesempatan pada industri gula dalam negeri untuk bisa berproduksi dan memperoleh keuntungan dibandingkan dengan mengimpor langsung gula konsumsi, baik konsumsi rumah tangga (gula kristal putih) dan konsumsi industri (gula kristal rafinasi).

Di dunia terdapat 10 negara pengekspor gula terbesar yakni diantaranya adalah Brazil, Thailand, Australia, India, Guatemala, EU-27, Mexico, Columbia, United Emirates Arab dan Cuba. Kesepuluh negara eksportir gula tersebut juga termasuk sebagai negara yang memasok gula mentah ke Indonesia, tabel 5.1 adalah gambaran impor gula mentah Indonesia berdasarkan negara asal pada periode waktu 2010 - 2012. 


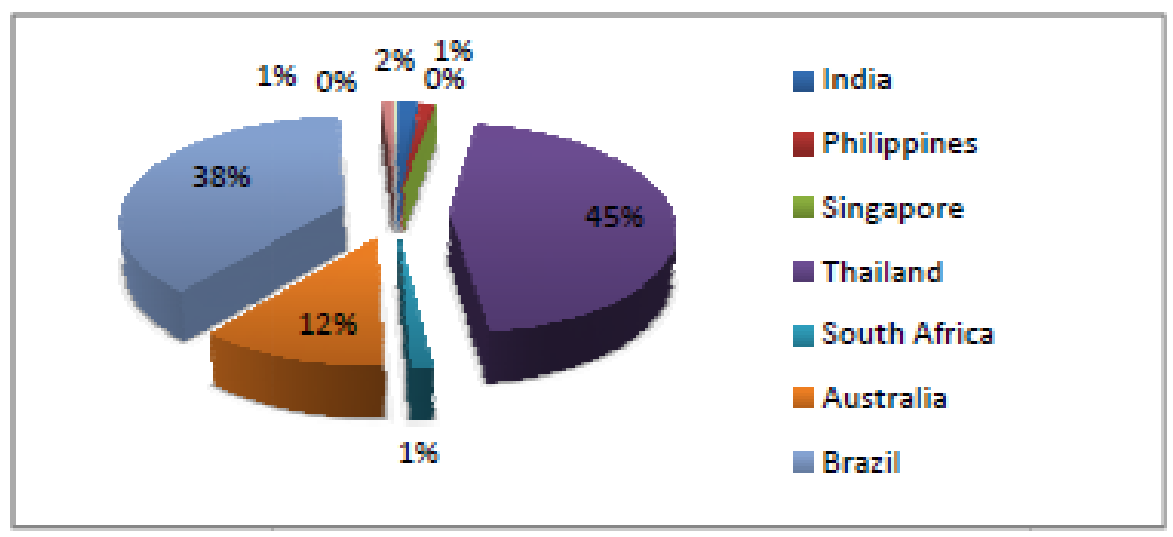

Gambar 1. Impor Gula Mentah Indonesia Berdasarkan Negara Asal Tahun 2010-2012 (Sumber: BPS, 2012)

Gambar 1. tersebut menggambarkan bahwa sebagian besar kebutuhan gula mentah Indonesia pada periode tahun 2010-2012 dipenuhi oleh tiga negara yakni Thailand, Brazil, dan Australia. Untuk melihat perkembangan volume impor gula kristal mentah di Indonesia dari waktu ke waktu, perlu dilakukan analisis trend. Dalam penelitian ini data volume impor yang dianalisis adalah volume impor gula kristal mentah di Indonesia dari tahun 1983 sampai tahun 2011.

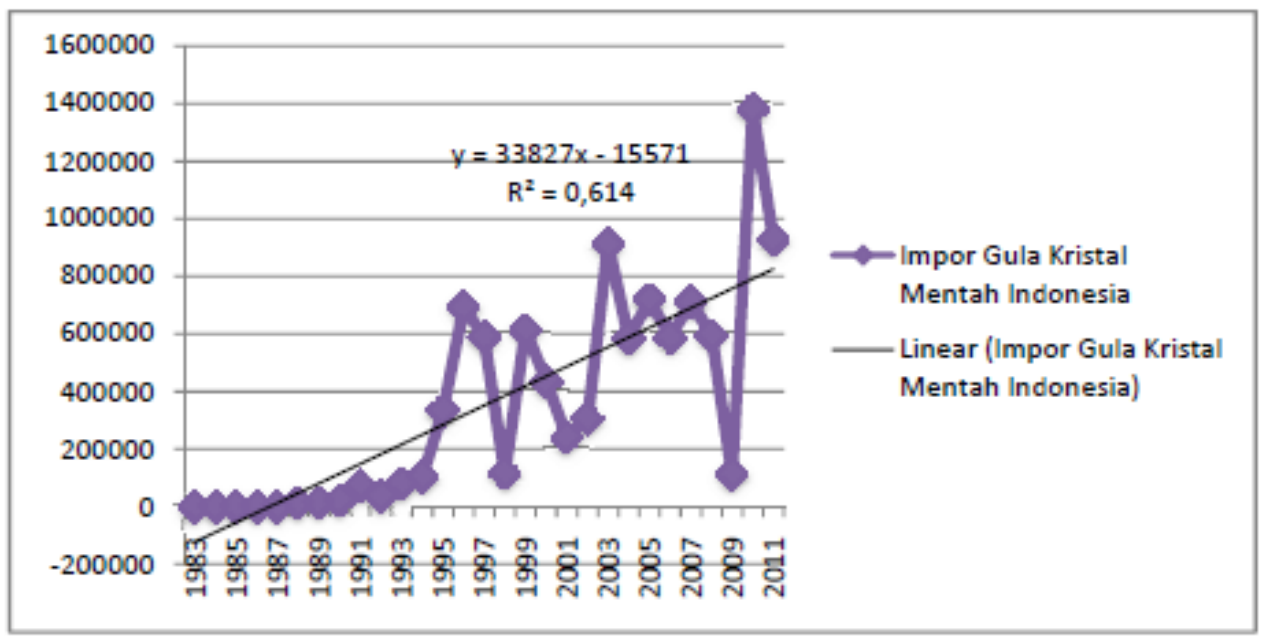

Gambar 2. Trend Jumlah Impor Gula Kristal Mentah Indonesia (Sumber : FAO, 2011)

Dari hasil plot antara jumlah impor gula kristal mentah Indonesia dengan waktu, ternyata menunjukkan hasil yang meningkat dengan seiring bertambahnya waktu. Hal tersebut dapat dilihat dari hasil plot yang cenderung menunjukkan pola naik dari kiri ke kanan. Hasil persamaan regresi yang didapat dari hasil plot antara jumlah impor gula kristal mentah Indonesia dengan waktu adalah sebagai berikut:

$\mathrm{Ir}=-15571+33827 \mathrm{~T}$

Berdasarkan hasil analisis trend tersebut dapat diperkirakan bahwa Indonesia pada tahun 2020 jumlah impor gula kristal mentahnya bisa mencapai 1.219.979 ton yang artinya meningkat sebesar 1,3 kali lipat dibandingkan dengan total impor gula kristal mentah Indonesia di tahun 2011.

Pertumbuhan impor gula kristal mentah Indonesia selama 29 tahun dari tahun 1998 hingga tahun 2011 mencapai 507,126\% per tahunnya. Hal tersebut terjadi dikarenakan pada tahun 1984 1987 Indonesia sama sekali tidak melakukan impor gula kristal mentah, namun pada tahun 1988 Indonesia mulai mengimpornya dalam jumlah yang besar yakni mencapai 12.610 ton. Jika pertumbuhan impor diperhitungkan setelah tahun tersebut, maka pertumbuhan impornya mencapai $99,84 \%$ per tahun.

Indonesia rata-rata mengimpor gula sebesar 6,03 persen dari total gula dunia dan khusus untuk gula kristal mentah, Indonesia 
mengimpor 100 persen dari total kebutuhan. Penurunan jumlah impor Indonesia terhadap gula mentah mengalami penurunan yang cukup besar pada tahun 1998, yakni pada saat terjadinya krisis moneter. Pada krisis moneter saat itu konsumsi gula Indonesia baik konsumsi rumah tangga dan konsumsi industri mengalami penurunan, sehingga tak mengherankan jika jumlah impor gula kristal mentah yang merupakan bahan baku juga ikut menurun jumlahnya.

Pada periode 1969 - 1975 dan 1983 1994 Indonesia mengalami surplus ekspor impor gula, dan untuk periode selanjutnya Indonesia selalu mengalami defisit ekspor impor gula. Bahkan pada periode 1996 - 2007 defisit neraca perdagangan gula Indonesia semakin besar dengan semakin banyaknya gula impor di pasaran domestik (Pusdatin, 2010). Berdasarkan gambar 2 sebelumnya dapat dilihat bahwa pada periode tahun 2007-2009, impor gula kristal mentah kian berkurang jumlahnya. Hal tersebut adalah salah satu dampak dari penerapan kebijakan pemerintah mengenai pembatasan impor sebagai langkah untuk mengendalikan gula impor yang masuk ke pasar gula dalam negeri. Namun, seiring dengan berkurangnya stok gula dalam negeri, maka dikeluarkan kebijakan penurunan bea masuk melalui Peraturan Menteri Keuangan No. 150/PMK.011/2009 pada tanggal 24 Sepetember 2009 dengan tujuan untuk meningkatkan volume impor sehingga pada tahun 2010 impor kembali mengalami peningkatan. Pengurangan tarifnya mencapai 40 persen per $\mathrm{kg}$ untuk gula kristal mentah, dari specific tariff sebesar Rp 250,00 per $\mathrm{kg}$ menjadi Rp 150,00. Sedangkan untuk gula kristal putih dan rafinasi mengalami penurunan tarif sebesar 25 persen per $\mathrm{kg}$, yakni dari $\mathrm{Rp}$ 530,00 per $\mathrm{kg}$ menjadi $\mathrm{Rp} 400,00$ per $\mathrm{kg}$. Peningkatan jumlah impor gula kristal mentah sebagai dampak dari pengurangan bea masuk pada periode tahun impor 2009 - 2010 yakni mencapai 1.266.662 ton. Peningkatan jumlah impor ini begitu signifikan, hal ini menunjukkan bahwa kebijakan pembatasan impor masih belum bisa dilaksanakan di Indonesia selama produksi gula dalam negeri masih belum bisa mengimbangi peningkatan jumlah konsumsi gula, dan dengan kata lain Indonesia masih sangat tergantung dengan impor gula dalam hal ini adalah gula kristal mentah.

Pada tahun 2013 diperkirakan konsumsi gula nasional mencapai 5,7 juta ton gula kristal putih dan rafinasi. Dari total kebutuhan gula ini hanya akan dipenuhi oleh produksi dalam negeri sekitar 3,7 juta ton, sehingga kekurangannya masih harus dipenuhi dari gula impor. Kebutuhan gula akan semakin meningkat seiring dengan pertambahan jumlah penduduk dan peningkatan industri makanan dan minuman.

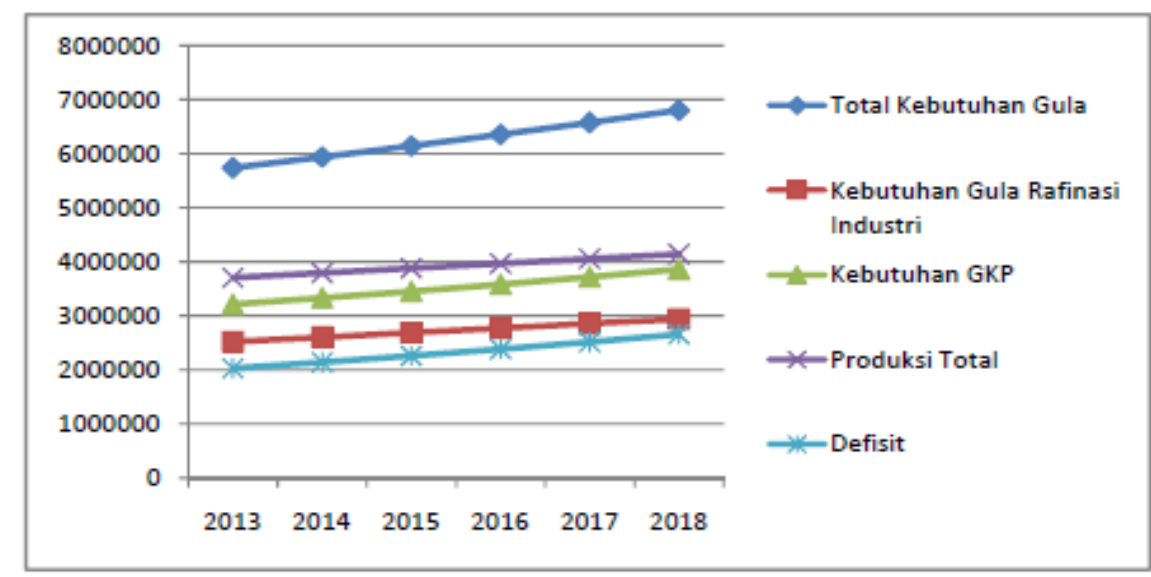

Gambar 3. Proyeksi Neraca Gula Nasional Tahun 2013-2018 (Sumber: Data Diolah, 2013)

Berdasarkan proyeksi pada gambar 3, dengan asumsi konsumsi gula nasional akan mengalami kenaikan sebesar 3,34 persen tiap tahunnya maka pada tahun 2018 konsumsi akan mencapai 6,8 juta ton. Sementara jika jumlah pabrik berproduksi tidak bertambah atau tetap, maka produksi dalam negeri hanya akan mampu memenuhi kebutuhan sebesar 4,1 juta ton dari keseluruhan kebutuhan gula dalam negeri. Dalam kondisi ini berarti Indonesia akan mengalami defisit sebesar 2,7 juta ton. Bentuk gula yang mengalami defisit adalah gula rafinasi, sedangkan untuk gula kristal putih masih bisa dipenuhi dengan produksi dalam negeri. Hal tersebutlah yang menuntut Indonesia untuk mengimpor gula 
dalam bentuk gula kristal mentah sebagai bahan baku produksi gula kristal rafinasi.

Neraca gula Indonesia kini menjadi sangat tidak menguntungkan, melihat proyeksi defisit yang akan semakin bertambah dari waktu ke waktu. Sementara di lain hal, harga gula dunia juga semakin tinggi. Semakin tingginya harga gula dunia dengan kebutuhan impor yang semakin besar, menyebabkan terciptanya kondisi yang tidak menguntungkan khususnya bagi produk yang masi berorientasi di dalam negeri.

Pemenuhan kebutuhan gula kristal mentah dapat ditempuh dengan mengoptimalkan pabrik gula kristal putih yang saat ini ada dan mengubah sebagian pabrik untuk menghasilkan gula kristal mentah serta membangun pabrik baru. Apabila diperhitungkan dengan asumsi musim giling gula adalah 150 hari setahun, dengan rendemen 10 persen dan kapasitas pabrik baru adalah 10.000 tcd, maka untuk menutup defisit gula dan mencapai swasembada gula, Indonesia perlu membuka minimum sejumlah 18 pabrik baru. Sedangkan untuk luasan lahan yang dibutuhkan yakni seluas 489.131 hektar dengan asumsi produksi per luas lahannya adalah 5,52 ton gula per hektar.

\section{KESIMPULAN}

1. Faktor yang berpengaruh secara signifikan terhadap permintaan gula kristal mentah impor adalah produksi gula kristal putih Indonesia, konsumsi gula nasional dan harga gula kristal mentah dunia. Impor gula kristal mentah akan terus meningkat per tahunnya seiring dengan meningkatnya jumlah konsumsi gula nasional, selama Indonesia tidak berupaya untuk mulai memproduksi gula kristal mentahnya sendiri.

2. Trend impor gula kristal mentah oleh Indonesia cenderung naik atau meningkat dari tahun ke tahun. Berdasarkan hasil analisis trend, dapat diperkirakan bahwa Indonesia pada tahun 2020 jumlah impor gula kristal mentahnya bisa mencapai 1.219 .979 ton yang artinya meningkat sebesar 1,3 kali lipat dibandingkan dengan total impor gula kristal mentah Indonesia di tahun 2011.

3. Swasembada gula dapat tercapai dengan membangun minimum 18 pabrik gula baru yang terdiri dari pabrik gula kristal putih dan gula kristal rafinasi dengan kapasitas produksi masing-masing 10.000 tcd. Selain itu, pembangungan tersebut juga harus diikuti dengan perluasan lahan tebu hingga minimal mencapai 489.131 hektar.

\section{DAFTAR PUSTAKA}

Badan Pusat Statistik. 2010. Statistik Tebu Indonesia 2010. BPS. Jakarta.

$$
\text { 2011. Statistik Tebu }
$$

Indonesia 2011. BPS. Jakarta.

FAO. 2011. Food Outlook - Global Market Analysis Juni 2011. p: 35-39. www.fao.org/docrep/018/al999e.pdf. Diakses tanggal 4 Juni 2013.

Krisnamukti, Bayu. 2012. Ekonomi Gula. PT. Gramedia Pustaka Utama. Jakarta.

Komisi Pengawas Persaingan Usaha. 2010. Position Paper Komisi Pengawas Persaingan Usaha Terhadap Kebijakan dalam Industri Gula. KPPU. Jakarta.

Pusat Data dan Informasi Pertanian. 2010. Outlook komoditas Pertanian - Perkebunan. Kementerian Pertanian. Jakarta. 